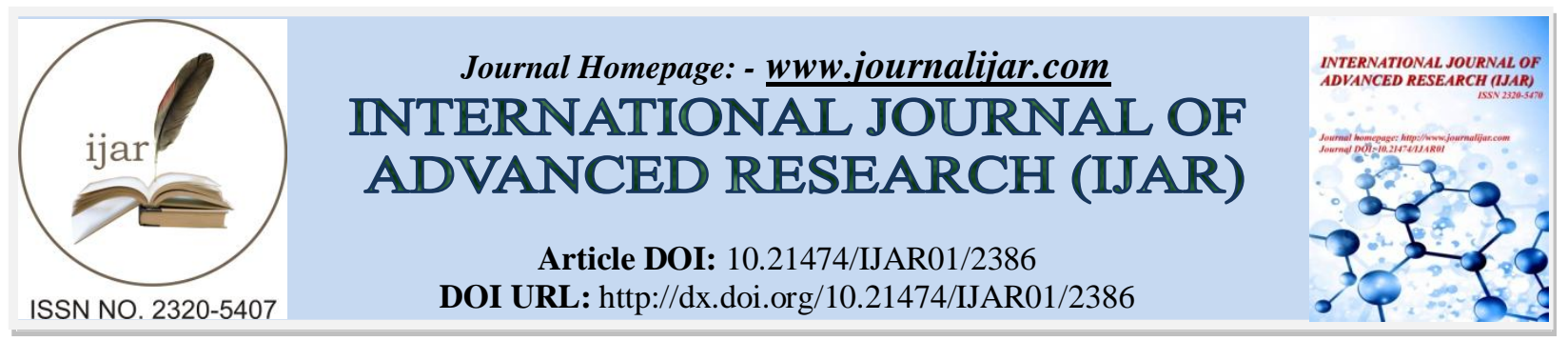

RESEARCH ARTICLE

\title{
ATTITUDE AND APTITUDE OF TEACHER EDUCATORS TOWARDS DEVELOPMENT OF COMPUTERIZED SELF INSTRUCTIONAL MATERIALS (CSIM) IN THEIR RELATED SUBJECTS.
}

Dr. Rajashekhar Shirvalkar.

Asst. Professor SMRS B.Ed College Kalaburagi.

\section{Manuscript Info}

Manuscript History

Received: 19 October 2016

Final Accepted: 20 November 2016

Published: December 2016

Key words:-

Attitude, Aptitude, CISM, Teacher

Educators, Subjects.

\section{Abstract}

This is an ICT era. Nowadays, technology plays an important role in enrichment of education system especially it gives an opportunity for teachers and learners to change their teaching and learning style. Present educational system requires output of ICT strengthen teachers. Teachers must have knowledge and creative skill of designing and development of instructional material for their own. It is only possible when teacher trainees provide facilities of technological supported practices in TTI. In India, Every year, thousands of teachers output from the training institutions. Some of teachers have attained good training from some good institutions. Among them few teachers are good at technology. Very few teachers get ICT based teaching learning practices. Less number of teachers shows interest towards preparation of their own instructional materials. Many teachers are depending on readymade teaching materials and follows traditional methods of teaching in the classroom. This is the major problem in production of quality teachers. Government expenses millions of rupees on education system for quality education. Nowadays it gives more importance and expense on ICT based education system from lower to higher education. Teachers must utilize such opportunities to facilitate their knowledge, skill and experience in development of quality education.

Copy Right, IJAR, 2016,. All rights reserved.

\section{Introduction:-}

Computerized instructional materials was first used as a tutoring tool for students in the $60 \mathrm{~s}$ and $70 \mathrm{~s}$, but over the past 30 years, it has evolved into software that incorporates some functions for helping students learn including drill and practice, tutorial, simulation, games, and problem solving. As you will find from the many examples in the web sites, it is difficult to define many of the instructional software packages into one category. Universities, software companies, and open source projects have all developed software for educational purposes that blends two or more categories of instructional software.

Today's instructional software also uses both objectivist and constructivist learning concepts in its design, which benefits the learner since both concepts are valuable to accomplishing educational goals for students. Educational software is valuable to all ages of students for many reasons including making learning more fun, motivating students, helping with long-term memory of the material, and providing a thorough educational experience that incorporates many proven learning concepts into the curriculum. Educational software is best used to augment 
classroom curriculums, but in most cases, should not be the only instructional method for learning. Educational software no longer is thought to be a replacement for teachers, but a tool that helps teachers do a better job of teaching their students. There are literally thousands of educational software packages that provide learning tools for all subject areas. Before purchasing any educational software, it is best to research the product to ensure it provides the intended learning goals for students.

\section{Significance of the study:-}

Development of self instructional material is an art and creative skill. Teacher must have skill of preparation of instructional materials for effective teaching. It requires mastery in subjects. Every teacher needs practice to develop instructional materials in school or at home. ICT lab and knowledge of instructional material is very necessary for development of CSIM. But many B.Ed Colleges have no such facilities and does not motivate to teacher educators to work with ICT. For this study qualitative and quantitative methods ware used. This study showed that many teacher educators were interested towards CISM but they were de motivated by the management and not co-operate from their colleagues. Many teacher educators responded that though they are experts in ICT but some institutions are not provide ICT facility for teaching quality enhancement. Some teacher educators expressed that it was extra work and burden for them. For that purpose researcher conducted the study.

\section{Objectives:-}

1. To study the computer aptitude of teacher educators.

2. To study attitude of teacher educators towards development of CSIM

3. To study the CSIM aptitude of teacher educators in respective subjects.

\section{Hypotheses:-}

1. There is no significant difference between male and female teacher educators attitude towards development of CSIM

2. There is no significant difference of teacher educators towards aptitude of CSIM with respect to different subjects.

3. There is a positive response of Science, Mathematics, Social Science and Language, teacher educators towards development of CSIM.

\section{Reviews of related Literature:-}

Hawkins (1998, p. 53) said, "Teachers should understand that technology is one of a variety of powerful teaching tools that are available to them, and tools just as they had to learn how to use a piece of chalk or an overhead projector, or a textbook, or any other tool that's available to them.

Das (1984) conducted a study on development of self instructional materials in Health education and to find out the effectiveness of self learning materials as compared to the conventional method of teaching. The result found to be superior to all other methods of learning and when administered under the supervision of a teacher was found to be more effective.

Jayalaxmi (1995) conducted a study on preparation of instructional module-validation and its effectiveness. The module was prepared for B.Ed students in Educational psychology at B.Ed level was quite effective.

\section{Variables:-}

The following variables are used for the study;

Independent Variables: teacher educators, male, female, CSIM, Subjects

Dependent Variables: Attitude and Aptitude

\section{Methodology:-}

Experimental and survey methods ware used for the study.

In the first stage is administration of computer aptitude test. This test was applied on 120 teacher educators to test computer skill of hands in experience. The collected scores are classified and analyzed using Chi square test and responses were analyzed using percentage and represented by graphs. 
The second stage was administration of CSIM Scale on the same samples. The collected data were analyzed with the help of graphical representation.

\section{Tools Used:-}

The researcher used two different tools for study. One is Aptitude Scale is used to test teacher educators' skills toward development of Computerized Self Instructional Materials. This tool is used to test hands in experience of teacher educators in development of CSIM. This tool is consisted 20 objective questions carried 20 marks.

Second one is Attitude Scale used for attitude of teacher educators toward development of Computerized Self Instructional Materials. This tool is self developed and is standardized. The reliability of this tool is 0.78 by split half method (Guttman) and internal consistency is 0.88 as measured by Cronchbach method. A reliability coefficient greater than 0.70 confirms that the scale used in the study is reliable. The face validity and content validity of the scale was ensured through consultation with faculty members.

\section{Sample:-}

The 120 teacher educators were selected from the B.Ed Colleges run under Gulbarga University Kalaburagi. There are 63 B.Ed Colleges are running under this university. The researcher randomly selected 120 teacher educators from 20 B.Ed Colleges having well equipped computer labs. Among them 60 male and 60 female teacher educators for different course were selected for the study. The distribution of sample shown as follow:

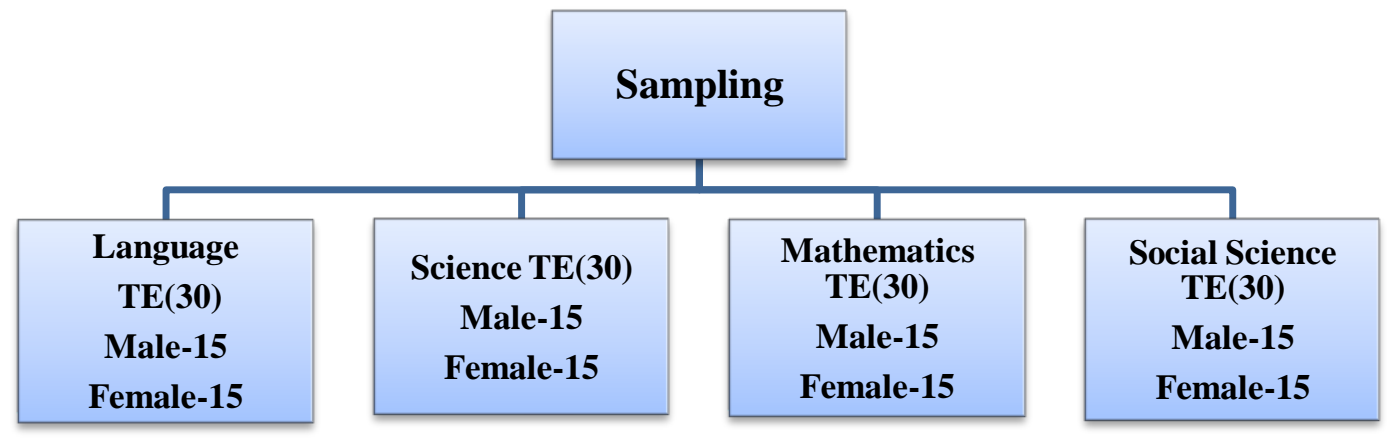

\section{Data Analysis:-}

Data are analyzed using SPSS software. The 2-tailed t-test was used for significance mean difference between male and female teacher educators with respect to different subject groups. The Chi square test was used for teacher educator's responses of attitude towards development of CSIM. The goodness of fit test was used for analyze the response scores. The normal distribution scores are considered to analyze skewness of responses of teacher educators. The Response scores were also analyzed using percentage with graphical representation.

1) Ho: There is no significance mean difference between male and female teacher educators aptitude towards development of CSIM with respect to different Subjects groups.

\begin{tabular}{|c|l|l|l|l|l|l|l|}
\hline Group.No & Pairs & N & M & SD & SEm & t-value & los \\
\hline 1. & ML - FL & 15 & 0.6000 & 4.08482 & 1.05469 & 0.569 & NS \\
\hline 2. & ML - FSc & 15 & 5.6000 & 3.04256 & 0.78558 & 7.128 & S \\
\hline 3. & ML - FM & 15 & 4.7333 & 2.34419 & 0.60527 & 7.820 & S \\
\hline 4. & ML - FSS & 15 & 0.0667 & 3.49421 & 0.90220 & 0.074 & NS \\
\hline 5. & MSc - FL & 15 & 4.4667 & 3.46135 & 0.89372 & 4.998 & S \\
\hline 6. & MSc - FSc & 15 & 1.7333 & 3.88158 & 1.00222 & 1.729 & NS \\
\hline 7. & MSc - FM & 15 & 0.8667 & 3.35659 & 0.86667 & 1.000 & NS \\
\hline 8. & MSc - FSS & 15 & 3.8000 & 3.76450 & 0.97199 & 3.910 & S \\
\hline 9. & MM - FL & 15 & 5.6667 & 2.60951 & 0.67377 & 8.410 & S \\
\hline 10. & MM - FSc & 15 & 0.5333 & 3.09069 & 0.79801 & 0.668 & NS \\
\hline 11. & MM - FM & 15 & 0.3333 & 3.13202 & 0.80868 & 0.412 & NS \\
\hline 12. & MM - FSS & 15 & 5.0000 & 3.77964 & 0.97590 & 5.123 & S \\
\hline 13. & MSS - FL & 15 & 0.6000 & 2.87352 & 0.74194 & 0.809 & NS \\
\hline
\end{tabular}




\begin{tabular}{|l|l|l|l|l|l|l|l|}
\hline 14. & MSS - FSc & 15 & 5.6000 & 3.50102 & 0.90396 & 6.195 & S \\
\hline 15. & MSS - FM & 15 & 4.7333 & 2.43389 & 0.62843 & 7.532 & S \\
\hline 16. & MSS - FSS & 15 & 0.0667 & 2.86523 & 0.73980 & 0.090 & NS \\
\hline 17. & ML - MSc & 15 & 3.8667 & 4.10342 & 1.05950 & 3.650 & S \\
\hline 18. & MSc - MM & 15 & 1.2000 & 3.38484 & 0.87396 & 1.373 & NS \\
\hline 19. & MM - MSS & 15 & 5.0667 & 2.91466 & 0.75256 & 6.733 & S \\
\hline 20. & FL - FSc & 15 & 6.2000 & 3.27763 & 0.84628 & 7.326 & S \\
\hline 21. & FSc - FM & 15 & 0.8667 & 2.94877 & 0.76137 & 1.138 & NS \\
\hline 22. & FM - FSS & 15 & 4.6667 & 2.94392 & 0.76012 & 6.139 & S \\
\hline 23. & ML - MSS & 15 & 0.0000 & 3.11677 & 0.80475 & 0.000 & NS \\
\hline 24. & FL - FSS & 15 & 0.6667 & 2.76887 & 0.71492 & 0.933 & NS \\
\hline
\end{tabular}

Digree of freedom(df) $=14$ at 0.05 level of significance

ML=Male-Language, MSc=Male-Science, MM=Male-Maths, MSS=Male Social Science, FL=Female-Language, $\mathrm{FSc}=\mathrm{Female}$-Science, $\mathrm{FM}=$ Female-Maths, FSS=Female Social Science, $\mathrm{S}=$ Significance, NS=Not Significance

From the above table, the result found that the groups of science and mathematics teachers compared with language and Social study teachers have high aptitude towards development of CSIM with respect to genders.

2) Ho: There is no significance difference of teacher educators attitude towards development of CSIM

\begin{tabular}{|c|c|c|c|c|c|c|}
\hline STATEMENTS & f & $\begin{array}{l}\text { Yes, I } \\
\text { can do } \\
\text { that. }\end{array}$ & $\begin{array}{l}\text { I think so, } \\
\text { but I am } \\
\text { not sure }\end{array}$ & $\begin{array}{l}\text { I don't know } \\
\text { how to do } \\
\text { that. }\end{array}$ & $\chi^{2}$ & $\begin{array}{l}\text { Los } \\
\text { at } \\
0.05\end{array}$ \\
\hline \multirow{2}{*}{$\begin{array}{l}\text { 1) Can you prepare your lessons on PPT } \\
\text { related to your subject content? }\end{array}$} & fo & 34 & 26 & 60 & \multirow[t]{2}{*}{135.99} & \multirow[t]{2}{*}{$\mathbf{S}^{*}$} \\
\hline & fe & 19.2 & 81.6 & 19.2 & & \\
\hline \multirow{2}{*}{$\begin{array}{l}\text { 2)Can you prepare Video base lessons } \\
\text { related to your subject content? }\end{array}$} & fo & 25 & 28 & 67 & \multirow[t]{2}{*}{155.96} & \multirow[t]{2}{*}{$\mathbf{S}^{*}$} \\
\hline & fe & 19.2 & 81.6 & 19.2 & & \\
\hline \multirow{2}{*}{$\begin{array}{l}\text { 3) Can you prepare Audio base lessons on } \\
\text { related to subject content? }\end{array}$} & fo & 28 & 30 & 62 & \multirow[t]{2}{*}{132.07} & \multirow[t]{2}{*}{$\mathbf{S}^{*}$} \\
\hline & fe & 19.2 & 81.6 & 19.2 & & \\
\hline \multirow{2}{*}{$\begin{array}{l}\text { 4)Can you prepare Digital lesson notes } \\
\text { (word/pdf) related to your subject content? }\end{array}$} & fo & 30 & 30 & 60 & \multirow[t]{2}{*}{125.40} & \multirow[t]{2}{*}{$\mathbf{S}^{*}$} \\
\hline & fe & 19.2 & 81.6 & 19.2 & & \\
\hline \multirow{2}{*}{$\begin{array}{l}\text { 5)Can you prepare open source software on } \\
\text { related to your subject content? (like PLM } \\
\text { s/w, MM s/w etc.) }\end{array}$} & fo & 7 & 19 & 94 & \multirow[t]{2}{*}{347.18} & \multirow[t]{2}{*}{$\mathbf{S}^{*}$} \\
\hline & fe & 19.2 & 81.6 & 19.2 & & \\
\hline \multirow{2}{*}{$\begin{array}{l}\text { 6)Can you prepare video clips on related to } \\
\text { your subject content? }\end{array}$} & fo & 25 & 27 & 68 & \multirow[t]{2}{*}{162.32} & \multirow[t]{2}{*}{$\mathbf{S}^{*}$} \\
\hline & fe & 19.2 & 81.6 & 19.2 & & \\
\hline \multirow{2}{*}{$\begin{array}{l}\text { 7)Can you down load PPT from the website } \\
\text { related to subject? }\end{array}$} & fo & 37 & 28 & 55 & \multirow[t]{2}{*}{118.46} & \multirow[t]{2}{*}{$\mathbf{S}^{*}$} \\
\hline & fe & 19.2 & 81.6 & 19.2 & & \\
\hline \multirow{2}{*}{$\begin{array}{l}\text { 8)Can you down load Doc. File and pdf } \\
\text { files from the website related to subject? }\end{array}$} & fo & 36 & 28 & 56 & \multirow[t]{2}{*}{120.44} & \multirow[t]{2}{*}{$\mathbf{S}^{*}$} \\
\hline & fe & 19.2 & 81.6 & 19.2 & & \\
\hline \multirow{2}{*}{$\begin{array}{l}\text { 9)Can you down load videos from the } \\
\text { website related to subject? }\end{array}$} & fo & 35 & 25 & 60 & \multirow[t]{2}{*}{138.96} & \multirow[t]{2}{*}{$\mathbf{S}^{*}$} \\
\hline & fe & 19.2 & 81.6 & 19.2 & & \\
\hline \multirow{2}{*}{$\begin{array}{l}\text { 10)Can you down load audios from the } \\
\text { website related to subject? }\end{array}$} & fo & 35 & 26 & 59 & \multirow[t]{2}{*}{133.39} & \multirow[t]{2}{*}{$\mathbf{S}^{*}$} \\
\hline & fe & 19.2 & 81.6 & 19.2 & & \\
\hline \multirow{2}{*}{$\begin{array}{l}\text { 11)Can you down load animated videos } \\
\text { from the website related to subject? }\end{array}$} & fo & 31 & 27 & 62 & 139.19 & $\mathbf{S}^{*}$ \\
\hline & fe & 19.2 & 81.6 & 19.2 & & \\
\hline 12)Can you down load Educational & fo & 33 & 25 & 62 & 144.59 & $\mathbf{S}^{*}$ \\
\hline $\begin{array}{l}\text { software from the website related to } \\
\text { subject? }\end{array}$ & fe & 19.2 & 81.6 & 19.2 & & \\
\hline 13)Can you use down loaded PPT from the & fo & 32 & 30 & 58 & 119.57 & $\mathbf{S}^{*}$ \\
\hline website related to subject? & fe & 19.2 & 81.6 & 19.2 & & \\
\hline 14)Can you use online videos related to & fo & 28 & 38 & 54 & 90.40 & $\mathbf{S}^{*}$ \\
\hline subject in the class room? & fe & 19.2 & 81.6 & 19.2 & & \\
\hline 15)Can you use online educational software & fo & 10 & 19 & 91 & 320.93 & $\mathbf{S}^{*}$ \\
\hline
\end{tabular}




\begin{tabular}{|c|c|c|c|c|c|c|}
\hline related to subject in the class room? & fe & 19.2 & 81.6 & 19.2 & & \\
\hline \multirow{2}{*}{$\begin{array}{l}\text { 16)Can you use CD-ROM's in the class } \\
\text { rooms related your subject? }\end{array}$} & fo & 21 & 39 & 60 & \multirow[t]{2}{*}{109.11} & \multirow[t]{2}{*}{$\mathbf{S}^{*}$} \\
\hline & fe & 19.2 & 81.6 & 19.2 & & \\
\hline \multirow{2}{*}{$\begin{array}{l}\text { 17)Can you purchase CD-ROMS' related to } \\
\text { your subject? }\end{array}$} & fo & 22 & 42 & 56 & \multirow[t]{2}{*}{90.16} & $\mathbf{S}^{*}$ \\
\hline & fe & 19.2 & 81.6 & 19.2 & & \multirow[t]{2}{*}{$\mathbf{S}^{*}$} \\
\hline \multirow{2}{*}{$\begin{array}{l}\text { 18)Can you use purchase on line software } \\
\text { related to your subject? }\end{array}$} & fo & 7 & 23 & 90 & \multirow[t]{2}{*}{310.91} & \\
\hline & fe & 19.2 & 81.6 & 19.2 & & $\mathbf{S}^{*}$ \\
\hline \multirow{2}{*}{$\begin{array}{l}\text { 19)Can you use any kind of teaching } \\
\text { learning packages like educom/edusoft etc. } \\
\text { in the class room? }\end{array}$} & fo & 7 & 27 & 86 & \multirow[t]{2}{*}{276.69} & \\
\hline & fe & 19.2 & 81.6 & 19.2 & & \\
\hline \multirow{2}{*}{$\begin{array}{l}\text { 20)Can you use desktop/Laptop/OHP in the } \\
\text { classroom? }\end{array}$} & fo & 15 & 34 & 71 & \multirow[t]{2}{*}{168.44} & \multirow[t]{2}{*}{$\mathbf{S}^{*}$} \\
\hline & fe & 19.2 & 81.6 & 19.2 & & \\
\hline
\end{tabular}

Degree of freedom $(\mathrm{df})=2$ at 0.05 level of significance, $S^{*}=$ Significant

The above table shows that the computed chi square values are greater than table chi square value (2.00) at 0.05 level of significant with df 2 . There is high significance difference between observed frequency and excepted frequencies. Hence the null hypothesis is rejected. The result stated that the teacher educators are highly positive attitude towards development of CSIM in their subjects.

The above

Table 1:- Response scores of teacher Educators attitude towards Development of CSIM.

\begin{tabular}{|l|l|l|l|}
\hline Responses & I can do & I think so & I can't do \\
\hline Language & $\mathbf{1 9 . 5 7 \%}$ & $\mathbf{3 4 . 5 1 \%}$ & $\mathbf{4 5 . 9 2 \%}$ \\
\hline Science & $\mathbf{6 8 . 1 7 \%}$ & $\mathbf{2 2 . 4 5 \%}$ & $\mathbf{9 . 3 8 \%}$ \\
\hline Maths & $\mathbf{6 3 . 7 8 \%}$ & $\mathbf{2 3 . 2 2 \%}$ & $\mathbf{1 3 \%}$ \\
\hline S.Study & $\mathbf{2 0 . 7 5 \%}$ & $\mathbf{2 3 . 7 9 \%}$ & $\mathbf{5 5 . 4 6 \%}$ \\
\hline
\end{tabular}

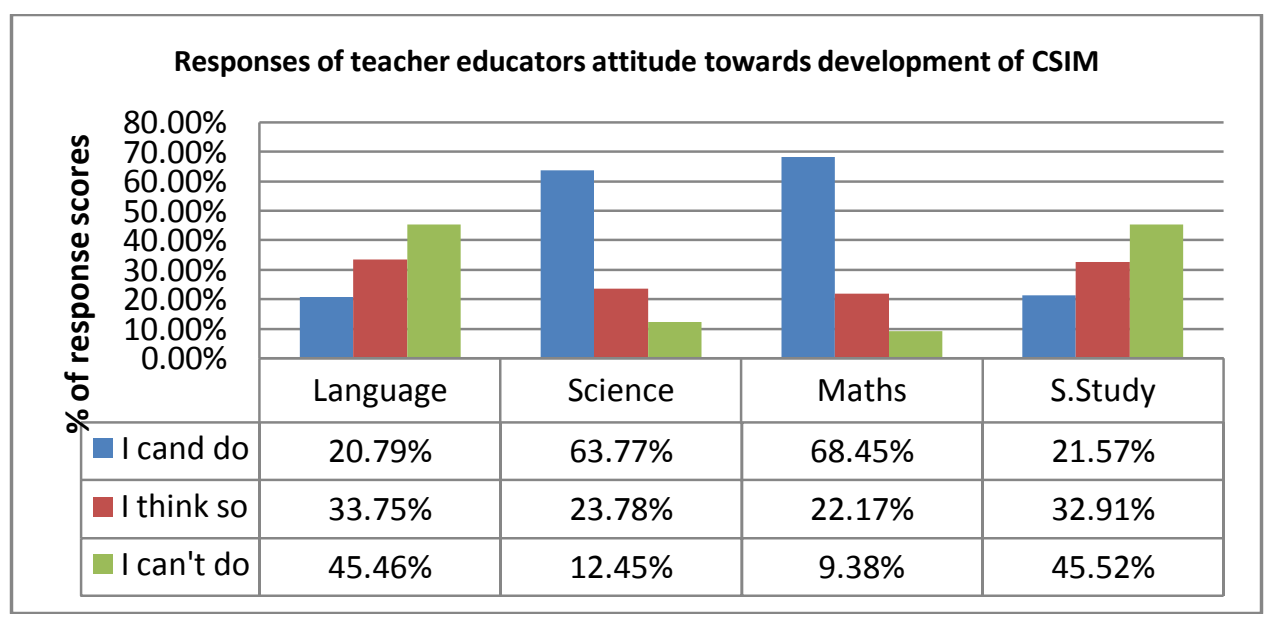

The above table and graph shows that Science and mathematics teacher educators are more positive attitudes than Language and Social Study teacher educators towards development of CSIM with respect to their subjects.

\begin{tabular}{|l|l|l|l|}
\hline Responses & I can do & I think so & I can't do \\
\hline Language & $\mathbf{1 9 . 5 7 \%}$ & $\mathbf{3 4 . 5 1 \%}$ & $\mathbf{4 5 . 9 2 \%}$ \\
\hline Science & $\mathbf{6 8 . 1 7 \%}$ & $\mathbf{2 2 . 4 5 \%}$ & $\mathbf{9 . 3 8 \%}$ \\
\hline Maths & $\mathbf{6 3 . 7 8 \%}$ & $\mathbf{2 3 . 2 2 \%}$ & $\mathbf{1 3 \%}$ \\
\hline S. Study & $\mathbf{2 0 . 7 5 \%}$ & $\mathbf{2 3 . 7 9 \%}$ & $\mathbf{5 5 . 4 6 \%}$ \\
\hline
\end{tabular}




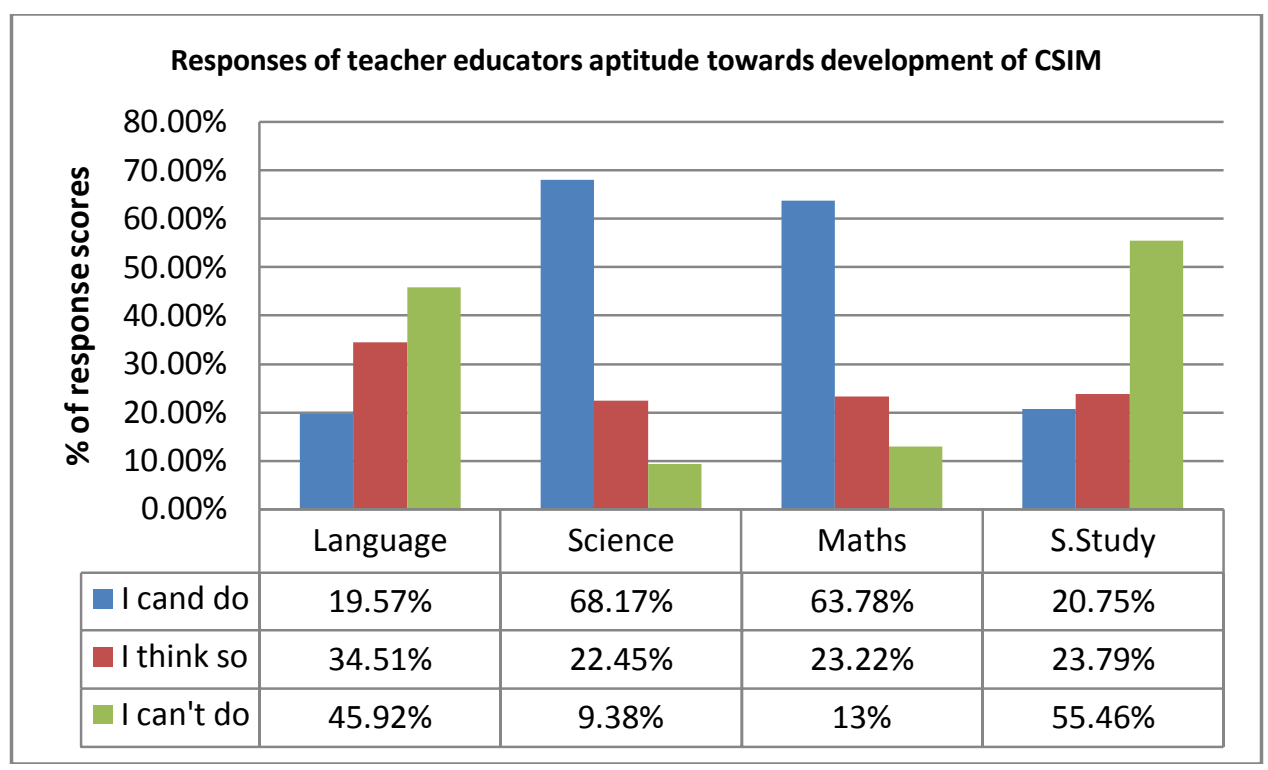

The above table and graph shows that Science and mathematics teacher educators are more positive aptitudes than Language and Social Study teacher educators towards development of CSIM with respect to their subjects.

\section{Major Findings of the study:-}

The study reveals the following findings

1) The result found that the groups of science and mathematics teachers compared with language and Social study teachers have high aptitude towards development of CSIM with respect to genders.

2) The teacher educators are highly positive attitude towards development of CSIM in their subjects.

3) The teacher educators attitude is more than the aptitude towards development of CSIM.

\section{Limitations of the study:-}

This study is limited to 120 teacher educators of B.Ed Colleges under Gulbarga University Kalaburagi. It was limited to computer attitude and aptitude tests and responses of teacher educators towards development of the CSIM.

\section{Further suggestions for the study:-}

This study will be further conducted in large scales. This research will be further experimented on pre-service, inservice teachers, UG and PG teachers attitude and aptitude towards development of computerized instructional materials.

\section{Conclusion:-}

This is computer age. Teachers must know how to develop instructional materials of their own subjects. Therefore computer knowledge is very important for teachers and students. They must familiar with computer based teaching and learning materials. Computerized instructional materials are the most attractive style of teaching and learning for users in the classroom. Teachers must have expand positive attitude towards use of CSIM and also develop their own instructional materials for teaching and learning process make effective. Teacher educators must individually develop skills of computerized self instructional materials for quality of teaching and learning.

\section{References:-}

1. Adhikari, R. (1992)"Development of Computer Aided Instruction Material on cell and cell reproduction for class IX”. In Goel, D. R. (2000). Educational Media in India. Delhi: Bharatiya Kala Prakashan, India.

2. Balasubramanian, N. and Meera, S. (2002). "Relative Effectiveness of Different Modes of Computer-Based instruction in Teaching Biology" EDU TRACKS, Vol. I, No.6,

3. March.)

4. Jothiokani, N. and Thiagarajan, A.P. (2004). "Effectiveness of Computer Assisted Instruction in Mathematics among B.Sc. Degree Students", Ph.D. Edu., Algappa University, Indian Educational Abstracts, NCERT, Vol. 4, No.2, July. 
5. Khirwadkar, A.(1998) "Development of Computer software for learning chemistry at standard XI." An unpublished Ph.D, Thesis, Vadodara: CASE, The M.S.University of Baroda, India,

6. Loyd,B.H \& Gressard, C.(1984 b). The effect of sex,age and computer experience on computer attitude. AEDS Journal, 18(2), 67, 77.

7. Malla Reddy Mamidi \& S.Ravishankar (1977)“Curriculum Development and Educational Technology” Indian Association for Programmed Learning Baroda

8. Nash, J.B. \& Moroz, P, (1997). Computer attitude among professional Educators: the role of gender and experience. Annual meeting of thr southwest of the Educational Research Association. Austin, TX, January 2325.

9. S.S. Chauhan (1983) "Innovations in Teaching Learning Process" Vikas Publishing House (U.P.). 